\title{
Pharmacological Induction of Neuroglobin Expression
}

\author{
Kunlin Jin Xiao Ou Mao Lin Xie Varghese John David A. Greenberg \\ Buck Institute for Age Research, Novato, Calif., USA
}

\section{Key Words}

Neuroglobin · Cinnamic acid · Valproic acid - Ischemia

\begin{abstract}
Neuroglobin (Ngb) is an intracellular, oxygen-binding neuronal protein with protective effects against ischemia and related pathological processes. To identify small molecules capable of inducing $\mathrm{Ngb}$ protein expression, which might have therapeutic benefit, we examined Ngb expression by Western blot in cultured HN33 (mouse hippocampal neuron $x$ N18TG2 neuroblastoma) cells. In addition to deferoxamine, which was shown previously to enhance Ngb levels, Ngb expression was increased by the short-chain fatty acids cinnamic acid and valproic acid ( $\geq 100 \mu \mathrm{mol} / \mathrm{l})$, but not by other short-chain fatty acids, histone deacetylase inhibitors, or anticonvulsants. Drugs that stimulate the expression of neuroprotective proteins like $\mathrm{Ngb}$ may have therapeutic potential in the treatment of stroke and other neurological disorders.
\end{abstract}

Copyright $\odot 2011$ S. Karger AG, Basel

\section{Introduction}

Neuroglobin $(\mathrm{Ngb})$ is an oxygen-binding protein related to hemoglobin and myoglobin, but expressed predominantly in neurons and endocrine cells [1]. Its ex- pression is transcriptionally induced by neuronal hypoxia and cerebral ischemia, against which it confers protection [2-5]. Overexpression of Ngb also protects neurons against $\beta$-amyloid [6,7], nitric oxide [8], and hydrogen peroxide [9] toxicity in vitro and attenuates histopathological and behavioral features in a murine model of Alzheimer's disease in vivo [6]. Although the mechanisms involved in the neuroprotective effect of Ngb are unknown, these observations suggest that measures which increase Ngb levels might have therapeutic benefit in hypoxic or ischemic brain disorders, including stroke.

Because mammalian $\mathrm{Ngb}$ is an intracellular protein that does not cross cell membranes [10], direct administration of Ngb is not a feasible therapeutic strategy. However, a small number of chemical agents have been shown to induce Ngb expression in vitro. These include cobalt and the iron chelator deferoxamine (DFO) [4], which also enhance levels of the hypoxia-inducible factors HIF-1 $\alpha$ and HIF- $2 \alpha$, and the heme (ferrous protoporphyrin IX) oxidation product hemin (ferric protoporphyrin IX) [11], which stimulates transcription, translation and assembly of hemoglobins [12]. Of interest, both DFO [13, 14] and hemin [15] improve outcome from focal cerebral ischemia in rats, although these effects have been attributed to the induction of HIF- $1 \alpha$ and heme oxygenase-1, respectively. DFO is used clinically in the treatment of iron intoxication related to thalassemia, but allergic reactions

\section{KARGER}

(C) 2011 S. Karger AG, Basel

Fax +41613061234 E-Mail karger@karger.ch www.karger.com www.karger.com/pha
David A. Greenberg

Buck Institute for Age Research

8001 Redwood Boulevard, Novato, CA 94945 (USA)

Tel. +1 4152092087

E-Mail dgreenberg@buckinstitute.org 
and pulmonary, renal and neurological toxicity may occur [16]. Hemin is used to treat acute porphyrias, but is expensive and unstable, and may produce severe phlebitis [17].

As a starting point for investigating possible pharmacological regulators that might be used to enhance $\mathrm{Ngb}$ expression during brain hypoxia or ischemia, we examined the effects of short-chain fatty acids found previously to induce fetal $(\gamma)$ globin expression [18].

\section{Materials and Methods}

To study the effects of potential Ngb inducers in vitro, we used HN33 (mouse hippocampal neuron $\times$ N18TG2 neuroblastoma) cells, which show induction of Ngb by hypoxia [4] and hemin [11], and protection from hypoxia by forced Ngb overexpression [4]. Cells were plated at $1 \times 10^{5}$ cells/well on uncoated, 24 -well plastic dishes and maintained as described [4]. Drugs were purchased from Sigma (St. Louis, Mo., USA), except for vorinostat (SAHA) (Cayman Chemical, Ann Arbor, Mich., USA). Cultures were treated with various concentrations of drugs, or with DFO as a positive control [4], and Western blotting was performed $24 \mathrm{~h}$ later using a polyclonal anti-Ngb antibody (Sigma), as described previously [4]. Additional controls consisted of HN33 cells transfected with full-length mouse Ngb cDNA cloned into a pcDNA 3.1 plasmid with CMV promoter (induced Ngb control), or HN33 cells transfected with the pcDNA 3.1 vector alone (baseline Ngb control) [4].

\section{Results}

Figure 1 shows that, as expected, Ngb expression was low in control HN33 cells and high in HN33 cells transfected with pcDNA 3.1-Ngb or treated with DFO. Of the short-chain fatty acids tested, cinnamic and valproic acids showed prominent induction of Ngb, whereas butyric, levulinic and succinic acids had little or no effect.

Fig. 1. Pharmacologic induction of Ngb protein expression in HN33 cells. a Western blot showing basal Ngb protein expression in wild-type (left) and Ngb-overexpressing (right) HN33 cells. b Western blots showing Ngb protein expression in wild-type HN33 cells exposed for 24 h to short-chain fatty acids (butyric, cinnamic, levulinic, succinic or valproic) or to DFO (positive control) at the concentrations indicated. c Average fold control induction of $\mathrm{Ngb}$ protein expression, normalized to actin expression, in wild-type HN33 cells exposed for $24 \mathrm{~h}$ to the same compounds at the same concentrations ( $\mathrm{n}=3 ;{ }^{*} \mathrm{p}<0.05$ compared to control). d Relationship of drug class to compounds that did (cinnamic and valproic acids) and did not significantly induce Ngb protein expression in HN33 cells.

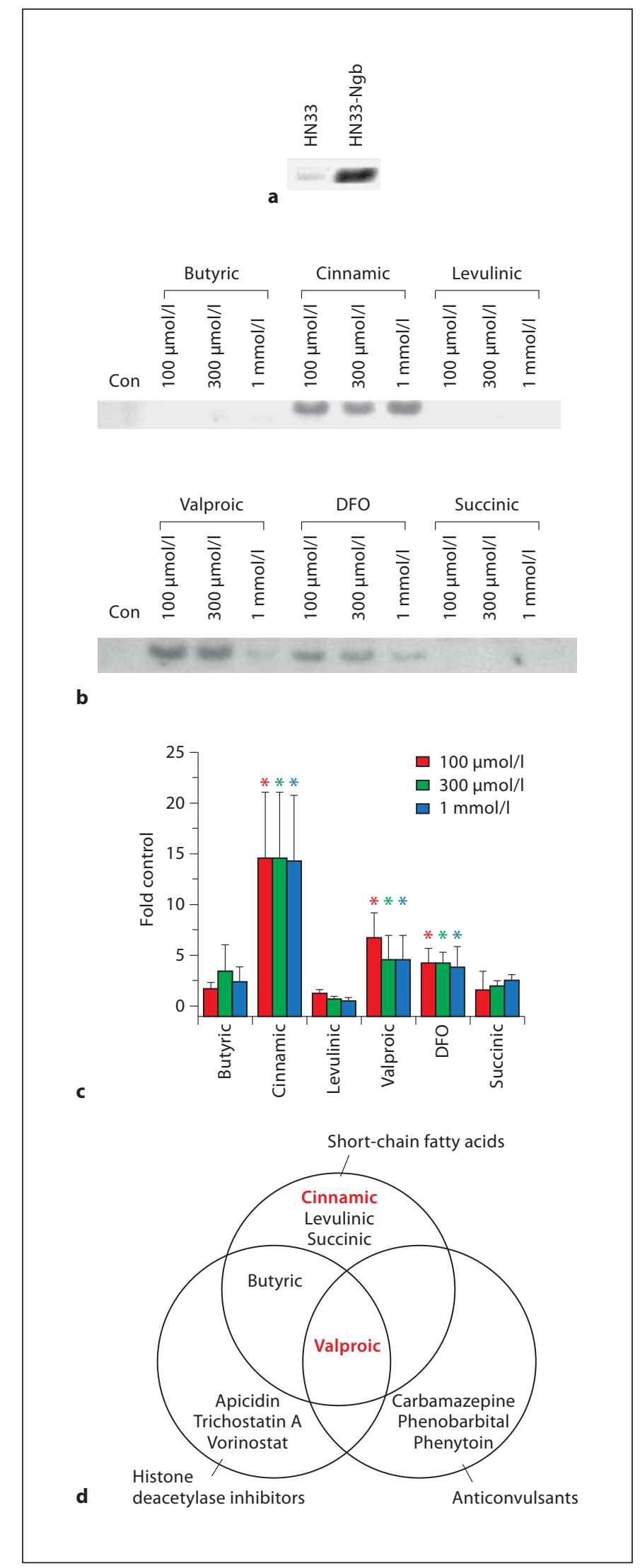


Some of the compounds we studied (e.g. valproic acid) are histone deacetylase (HDAC) inhibitors, and HDAC inhibitors are transcriptional activators, some of which exhibit neuroprotective effects [19], including beneficial effects on outcome from experimental stroke [20]. Therefore, we next investigated whether more potent and specific HDAC inhibitors also stimulate Ngb expression. The compounds chosen were the pan-HDAC inhibitors trichostatin A and vorinostat (SAHA) and the HDAC2and HDAC-3 selective inhibitor apicidin [21]. However, neither trichostatin A $(0.5-30 \mu \mathrm{mol} / \mathrm{l})$, SAHA (5-100 $\mu \mathrm{mol} / \mathrm{l})$, nor apicidin $(1-30 \mu \mathrm{mol} / \mathrm{l})$ increased $\mathrm{Ngb}$ levels detected by Western blot (not shown). Therefore, the $\mathrm{Ngb}$-inducing effects of drugs like valproic acid are unlikely to be due to HDAC inhibition.

Considering that the anticonvulsant valproic acid was among the most effective inducers of $\mathrm{Ngb}$ that we observed, and since valproic acid $[20,22]$ and other anticonvulsants $[23,24]$ are reported to be neuroprotective in some models of stroke, we examined whether a broader range of anticonvulsants might have $\mathrm{Ngb}$-inducing activity. Phenytoin $(20 \mu \mathrm{g} / \mathrm{ml})$, phenobarbital $(40 \mu \mathrm{g} / \mathrm{ml})$, carbamazepine $(12 \mu \mathrm{g} / \mathrm{ml})$ and gabapentin $(10 \mu \mathrm{g} / \mathrm{ml})$ were tested at concentrations typically found in the blood of patients treated for seizures. However, none increased Ngb levels on Western blots (not shown).

\section{Discussion}

Although several studies have shown a neuroprotective effect of Ngb against hypoxia, ischemia and other disorders, therapeutic application of this effect is problematic. $\mathrm{Ngb}$ is an intracellular protein that, except in zebrafish [10], is not known to cross cell membranes, making its direct administration unlikely to be effective. However, small molecules like DFO [4], hemin [11], and cinnamic and valproic acids (this report) appear capable of inducing $\mathrm{Ngb}$ protein expression in cultured neurons. Both DFO $[13,14,25,26]$ and valproic acid $[20,22]$ are protective in rodent models of cerebral ischemia, but whether induction of $\mathrm{Ngb}$ contributes to their protective actions is unclear. Cinnamic acid reduced glutamate toxicity in primary rat cortical neurons cultures [27], but did not protect GT1-7 (immortalized mouse hypothalamic) cells from oxygen and glucose deprivation [28] in vitro. Whether these or other drugs can induce Ngb expression in vivo at subtoxic doses, and whether the extent of Ngb induction achieved in this manner will be sufficient to afford protection are unclear, and will require further study.

\section{Acknowledgement}

Supported by NIH grant NS62040 to D.A.G.

\section{References}

1 Burmester T, Weich B, Reinhardt S, Hankeln $\mathrm{T}$ : A vertebrate globin expressed in the brain. Nature 2000;407:520-523.

-2 Khan AA, Mao XO, Banwait S, DerMardirossian CM, Bokoch GM, Jin K, Greenberg DA: Regulation of hypoxic neuronal death signaling by neuroglobin. FASEB J 2008;22: 1737-1747.

-3 Khan AA, Wang Y, Sun Y, Mao XO, Xie L, Miles E, Graboski J, Chen S, Ellerby LM, Jin K, Greenberg DA: Neuroglobin-overexpressing transgenic mice are resistant to cerebral and myocardial ischemia. Proc Natl Acad Sci USA 2006;103:17944-17948.

-4 Sun Y, Jin K, Mao XO, Zhu Y, Greenberg DA: Neuroglobin is upregulated by and protects neurons from hypoxic-ischemic injury. Proc Natl Acad Sci USA 2001;98:15306-15311.

5 Sun Y, Jin K, Mao XO, Zhu Y, Greenberg DA: Neuroglobin protects the brain from experimental stroke in vivo. Proc Natl Acad Sci USA 2003;100:3497-3500.
6 Khan AA, Mao XO, Banwait S, Jin K, Greenberg DA: Neuroglobin attenuates $\beta$-amyloid neurotoxicity in vitro and transgenic $\mathrm{Al}$ zheimer phenotype in vivo. Proc Natl Acad Sci USA 2007;104:19114-19119.

$\checkmark 7$ Li RC, Pouranfar F, Lee SK, Morris MW, Wang Y, Gozal D: Neuroglobin protects PC12 cells against $\beta$-amyloid-induced cell injury. Neurobiol Aging 2008;29:1815-1822.

$\checkmark 8$ Jin K, Mao XO, Xie L, Khan AA, Greenberg DA: Neuroglobin protects against nitric oxide toxicity. Neurosci Lett 2008;430:135-137.

$\checkmark 9$ Li RC, Morris MW, Lee SK, Pouranfar F, Wang Y, Gozal D: Neuroglobin protects PC12 cells against oxidative stress. Brain Res 2008;1190:159-166.

10 Watanabe S, Wakasugi K: Zebrafish neuroglobin is a cell-membrane-penetrating globin. Biochemistry 2008;47:5266-5270.

11 Zhu Y, Sun Y, Jin K, Greenberg DA: Hemin induces neuroglobin expression in neural cells. Blood 2002;100:2494-2498.

12 Rutherford TR, Clegg JB, Weatherall DJ: K562 human leukaemic cells synthesise embryonic haemoglobin in response to haemin. Nature 1979;280:164-165.
13 Freret T, Valable S, Chazalviel L, Saulnier R, Mackenzie ET, Petit E, Bernaudin M, Boulouard M, Schumann-Bard P: Delayed administration of deferoxamine reduces brain damage and promotes functional recovery after transient focal cerebral ischemia in the rat. Eur J Neurosci 2006;23:1757-1765.

14 Palmer C, Roberts RL, Bero C: Deferoxamine posttreatment reduces ischemic brain injury in neonatal rats. Stroke 1994;25:10391045

15 Takizawa S, Hirabayashi H, Matsushima K, Tokuoka K, Shinohara Y: Induction of heme oxygenase protein protects neurons in cortex and striatum, but not in hippocampus, against transient forebrain ischemia. J Cereb Blood Flow Metab 1998;18:559-569.

16 Olivieri NF, Brittenham GM: Iron-chelating therapy and the treatment of thalassemia. Blood 1997;89:739-761.

17 Anderson KE, Bloomer JR, Bonkovsky HL, Kushner JP, Pierach CA, Pimstone NR, Desnick RJ: Recommendations for the diagnosis and treatment of the acute porphyrias. Ann Intern Med 2005;142:439-450. 
18 Pace BS, White GL, Dover GJ, Boosalis MS, Faller DV, Perrine SP: Short-chain fatty acid derivatives induce fetal globin expression and erythropoiesis in vivo. Blood 2002;100: 4640-4648.

19 Kazantsev AG, Thompson LM: Therapeutic application of histone deacetylase inhibitors for central nervous system disorders. Nat Rev Drug Discov 2008;7:854-868.

-20 Kim HJ, Rowe M, Ren M, Hong JS, Chen PS, Chuang DM: Histone deacetylase inhibitors exhibit anti-inflammatory and neuroprotective effects in a rat permanent ischemic model of stroke: multiple mechanisms of action. J Pharmacol Exp Ther 2007;321:892-901.

-21 Khan N, Jeffers M, Kumar S, Hackett C, Boldog F, Khramtsov N, Qian X, Mills E, Berghs SC, Carey N, Finn PW, Collins LS, Tumber A, Ritchie JW, Jensen PB, Lichenstein HS, Sehested M: Determination of the class and isoform selectivity of small-molecule histone deacetylase inhibitors. Biochem J 2008;409:581-589.
22 Ren M, Leng Y, Jeong M, Leeds PR, Chuang DM: Valproic acid reduces brain damage induced by transient focal cerebral ischemia in rats: potential roles of histone deacetylase inhibition and heat shock protein induction. J Neurochem 2004;89:1358-1367.

23 Minato H, Kikuta C, Fujitani B, Masuda Y: Protective effect of zonisamide, an antiepileptic drug, against transient focal cerebral ischemia with middle cerebral artery occlusion-reperfusion in rats. Epilepsia 1997;38 975-980.

24 Williams AJ, Tortella FC, Lu XM, Moreton JE, Hartings JA: Antiepileptic drug treatment of nonconvulsive seizures induced by experimental focal brain ischemia. J Pharmacol Exp Ther 2004;311:220-227.

25 Hanson LP, Roeytenberg A, Martinez PM, Coppes VG, Sweet DC, Rao RJ, Marti DL, Hoekman JD, Matthews RB, Frey WH 2nd, Panter SS: Intranasal deferoxamine provides increased brain exposure and significant protection in rat ischemic stroke. J Pharmacol Exp Ther 2009;330:679-686.
26 Sarco DP, Becker J, Palmer C, Sheldon RA, Ferriero DM: The neuroprotective effect of deferoxamine in the hypoxic-ischemic immature mouse brain. Neurosci Lett 2000; 282:113-116

27 Kim SR, Kim YC: Neuroprotective phenylpropanoid esters of rhamnose isolated from roots of Scrophularia buergeriana. Phytochemistry 2000;54:503-509.

-28 Fallarero A, Peltoketo A, Loikkanen J, Tammela P, Vidal A, Vuorela P: Effects of the aqueous extract of Bryothamnion triquetrum on chemical hypoxia and aglycemiainduced damage in GT1-7 mouse hypothalamic immortalized cells. Phytomedicine 2006;13:240-245. 